\title{
Principles of Jordan Imports and Tariff Regimes
}

\author{
Bashar H. Malkawi*
}

\begin{abstract}
Customs law and procedures are important part of the trade system in Jordan. They regulate the flow of goods across the borders. The purpose of this paper is to examine Jordan's import regime by analyzing customs law, rules of origin, free trade zones, and tariffs reform.
\end{abstract}

Key words: WTO, Jordan, customs law, free trade, imports, tariffs

\section{Introduction}

When a country joins the WTO, it enjoys market access, i.e. entry and exit, rights. In return, an acceding country must offer equivalent market access concessions. For purposes of tariff reduction, products and their tariff lines are grouped together into several categories in what seems to be a sectoral approach. ${ }^{1}$

Jordan made substantial market access commitments as part of its WTO membership negotiations. ${ }^{2}$ It has low average tariffs with single or two digits rate, ad valorem-only duties with some exceptions where specific duties apply, and nearly 100 percent tariff bindings. ${ }^{3}$ Jordan may have binding overhangs, difference between bound tariff rates and

\footnotetext{
* Bashar Malkawi is Dean and Professor of Law at the University of Sharjah, United Arab Emirates. He holds S.J.D in International Trade Law from American University, Washington College of Law and LL.M in International Trade Law from the University of Arizona.

${ }^{1}$ See Staging Annex, Jordan Schedule of Market Access on Goods at <http://www.wto.org/english/thewto_e/countries_e/jordan_e.htm>. It is unclear how Jordan made its decision to group products and their tariff lines into categories and/or lower its import tariffs. Perhaps, it fixed reduced import tariffs according the situation or sensitivity of the domestic industry defined by the level of import penetration, productivity, job losses, and prices.

${ }^{2}$ This is despite Jordan's efforts in convincing WTO members that further tariff cuts would damage its fragile economy in 1998 with mounting trade deficit.

${ }^{3}$ Jordan agreed to impose zero or very low tariffs on all chemical products perhaps in light of the Chemical Tariff Harmonization Agreement of the Uruguay Round ("CTHA"). Specific duties, as opposed to ad valorem duties, are not transparent and have the effect of increasing trade protectionism.
} 
applied tariff rates, in its tariff schedule. ${ }^{4}$ To deal with sensitivities in tariffs reduction, Jordan was granted staging and product exclusion rights. ${ }^{5}$ While Jordan has a longer implementation period for tariff reductions, it made some degree of cuts several months from the date it acceded therefore securing for other countries some immediate tangible results from the negotiations.

The tariff reductions did not require changes in Jordanian internal law. Customs Law of 1998 provides that goods entering Jordan would be subject to customs duties prescribed in the customs law and if there is a special provision for a tariff in an international agreement to which Jordan is a party, a tariff shall be imposed in accordance with the provision of such agreement. ${ }^{6}$ Additionally, Council of Ministers will issue decisions related to tariff changes. ${ }^{7}$ Regarding compliance with the WTO's ITA, Jordan included its amended tariff schedule in its WTO accession agreements, thus negating the need to make changes in its internal law and to submit separate modification document to indicate compliance as required by the WTO's ITA.

In total, Jordan made tariff concessions with regard to 2790 tariff lines for industrial products and 462 tariff lines for agricultural products. ${ }^{8}$ The imbalance of tariff concessions between industrial and agricultural products might be interpreted to Jordan's emphasis on industrial products in international trade rather than on agricultural products.

\footnotetext{
${ }^{4}$ Bound tariff rates are the maximum tariffs Jordan can apply under its WTO commitments. Applied tariff rates are the actual tariffs in place.

${ }^{5}$ Jordan has a 10 -year transition period for implementing reduction commitments. Tobacco and alcohol maintain high tariff peaks. See Daniel Pruzin, WTO Approves Accession of Jordan to Trade Body, 17 Int'l. Trade. Rep. 29 (BNA) (Jan. 6, 2000). See also Working Party Report, at para. 55. It is noticeable that rather than outright prohibition on imports of tobacco and alcohol, Jordan opted to impose higher prohibitive tariffs between 150 percent and 200 percent.

${ }^{6}$ See Customs Law No. 20 of 1998, art. 9.

${ }^{7}$ Id. art. 14.

${ }^{8}$ See Jordan Schedule of Market Access on Goods.
} 
Jordan's average tariff ceilings represent what is prevailing in other Arab countries such as United Arab Emirates. ${ }^{9}$ These rates could provide Arab trade negotiators with a bargaining leverage in future multilateral trade rounds, a venue to protect some domestic industries, raise revenue, and income redistribution. However, there would be one snag for relying on tariffs as a bargaining leverage in negotiations. Over several rounds, large number of countries would have low tariffs, thus Jordan would be deprived of bargaining power. This is a scenario where the law of diminishing return would apply.

\section{Customs Law}

Customs law and procedures are important part of the trade system in Jordan. They regulate the flow of goods across the borders. One of the main functions of the Customs Department, an agency established in 1926 with 2236 current staff, is clearance of goods. Importers seeking to introduce goods into Jordan must file the appropriate documents and follow certain procedures and entry techniques. In some instances, traders could face opaque customs procedures associated with customs transactions. ${ }^{10}$

Jordan requires consularization or legalization of commercial bills by Jordanian consulates and chambers of commerce in the country of exportation for goods intended for export to Jordan. ${ }^{11}$ Consularization or legalization of commercial bills may not be warranted. It adds costs to traders and could be in effect a non-tariff trade barrier.

\footnotetext{
${ }^{9}$ The United Arab Emirates agreed to bind its tariff on all imported goods except in the case of some agricultural and dairy products (100\%), alcohol, tobacco, and pork (200\%).

${ }^{10}$ See PETE W. MOORE, DOING BUSINESS IN THE MIDDLE EAST: POLITICS AND ECONOMIC CRISIS IN JORDAN AND KUWAIT 162, 166 (2004) (stating that some traders are concerned about the increase in the size and power of the Customs Department. They claim that bureaucratic problems with the Department are legion. Sometimes, completing a customs importation document requires 17 signatures). ${ }^{11}$ Jordan committed to phase out consularization of commercial bills by Dec. 31, 2002. See Working Party Report, at 72. So far, Jordan has yet to rectify the practice of consularization as it committed itself to on the first day of 2003. For example, as of 2005, embassy of Jordan in Washington, D.C requires legalization of commercial bills. Legalization fee is $\$ 84$ per document. Commercial bills must also be legalized by the National U.S.-Arab Chamber of Commerce.
} 
Goods may enter Jordan for consumption, transit, warehousing, temporary importation, inward processing, or enter into a foreign trade zone. ${ }^{12}$ These different forms of entry could be designed to serve the different interests of importers. Warehousing, entry into a foreign trade zone, and inward processing share one common feature which is deferral of customs duties. ${ }^{13}$ Deferral of customs duties may help the financial situation of importers.

The owner of imported articles or his designated customs broker must file a customs declaration at the port of entry. ${ }^{14}$ The customs declaration could be accompanied by certificate of origin, bill of lading, or air waybill. Imported articles cannot be withdrawn unless customs procedures are completed and duties are paid. ${ }^{15}$ However, Customs Law of 1998 makes provisions for releasing imported articles before final payment of tariffs or settling other customs issues provided that payment of tariffs can be insured through cash, bonds or other financial guarantees. ${ }^{16}$ A system of posting financial guarantees separates between clearance of goods and customs matters such as tariffs. Depositing financial guarantees protects the government by securing tariffs owed while at the same time expedites clearance of goods for importers. However, small importers may find it difficult to deposit financial guarantees.

Customs Law of 1998 provides the right of appeal against Customs rulings initially within the Customs Department. ${ }^{17}$ Additionally, decisions of the Customs Department

\footnotetext{
${ }^{12}$ See Customs Law No. 20 of 1998, art. 65, Official Gazette No. 4305 (Oct. 1, 1998) as amended by Law No. 27 of 2000, Official Gazette No. 4443 (July 2, 2000).

${ }^{13} I d$. arts. $88,104,122 \& 133$.

${ }^{14} I d$. art. 61.

${ }^{15}$ Customs procedures include inspection and laboratory testing and analysis. Id. arts. $69,73 \& 82$. Inspection and testing of imported articles suggest delays depending on the number of samples. ${ }^{16}$ Id. arts. $75,82,83,85 \& 87$.

${ }^{17}$ A committee of three senior officials within the Customs Department would examine disputes concerning value, origin, characteristics or tariff classification of imported articles. Id. art. 80.a.
} 
may be contested before the Customs Court. ${ }^{18}$ The emphasis should be placed on administrative appeal, rather than judicial appeal, procedures which could resolve any customs-related dispute at quicker rate and lower costs for importers.

The Customs Department of Jordan is aggressively overhauling customs procedures by moving to upgrade its customs facilities and automate some aspects of the paper-based customs system. Moreover, it adopted many concepts and practices of trade facilitation. For example, the Customs Department provides green lane treatment to companies through expedited shipments free of or with de minimis inspections upon arrival at ports of entry. ${ }^{19}$ Movement and clearance of imported articles would be based on riskmanagement technique which is a methodical process for identifying high-risk shipments. ${ }^{20}$ The risk-management system would allow speedy clearance of low value or low volume imports. It also allows speedy clearance for articles imported by a reliable company that has a long history of compliance with the Customs Department rules.

Although the adoption of risk-management techniques are first steps in the right direction, it will take time and resources to truly effectuate these techniques. Additionally, since Jordan depends to certain degree on tariffs, the role of the Customs Department would be devoted largely to collecting revenue for the treasury. Customs

\footnotetext{
${ }^{18}$ Customs Law of 1998 establishes Customs Court of First Instance and Customs Court of Appeal. In certain circumstances, decisions of the Customs Court of Appeal could be appealed before Court of Cassation. Id. arts. 80.d, 222.a, 224.a \& 225.

${ }^{19}$ See Selectivity in the ASYCUDA System, at <http://www.customs.gov.jo/publication.asp> (last visited March 4, 2005).

${ }^{20}$ See Customs Law No. 20 of 1998, art. 84. The idea of inspecting all imported articles is impractical and a poor use of limited resources. The risk-management technique limits the physical inspection of imported articles. It includes random sampling at different rates. The technique starts with the Customs Department when goods are imported and continues through inspection. All information related to goods will enter into a computerized system that would enable inspectors for later retrieval.
} 
officials may delay imported articles for hours or days waiting verification as to classification and valuation. $^{21}$

The Customs Department makes available customs related laws, regulations, administrative rules, information on customs process, conditions for importation, charges applicable to Customs Law, tariff rates, tariff classification opinions, and bilateral and regional trade agreements. ${ }^{22}$ The Customs Department provides advanced rulings based on request from traders who seek clarification on specific matters such as classification and applicable tariff rates. Advance rulings prior to importation provide certainty and cut delays. This would help small and medium-sized companies before entering into commercial transactions.

\section{Tariff Classification and Valuation}

Every imported product enters into Jordan must be classified and valued. Selecting the appropriate tariff classification is significant for an importer because it determines the tariff rate that will be imposed. Usually, importer categorizes an imported article providing the lowest tariff rate.

There are several means used to classify imported products. These include description, physical characteristic, and use. The issue of tariff classification leads to divergent administrative and judicial interpretations. Courts in Jordan rendered their decisions on the proper classification of imported products based on one or more of these means.

\footnotetext{
${ }^{21}$ Until there is further lowering of tariffs, there could be mistrust between customs officials and importers regarding smuggling and under-valuation for purpose of evading payment of tariffs.

${ }^{22}$ The information is available at the Customs Department website with translation in English. See $\langle$ http://www.customs.gov.jo>.
} 
The question presented in one case pertained to the appropriate classification of imported tractor for semi-trailers. ${ }^{23}$ The Customs Department divided the imported tractor for semi-trailers into tractor classified under item $87 / 4$ of the tariff schedule subject to 400 fils per kilo weight and semi-trailers classified under item 87/14 subject to $40 \%$ ad valorem duty rate. The plaintiff contested that classification and claimed that the imported tractor for semi-trailers was properly classified under item $87 / 1 / \mathrm{b}$ duty-free. ${ }^{24}$ The Court of Cassation concluded that imported tractor for semi-trailers fell under item $87 / 1 / \mathrm{b}$ based on the name, description, and the specific use of tractors for hauling semitrailers whereby a coupling device, located behind the chassis, is used to hold semitrailers. ${ }^{25}$ The Court of Cassation seemed to consider tractor for semi-trailers as an entirety rather than divided into parts because each part could not be used independently.

In another case, the Court of Cassation affirmed the conclusion of Customs Court of Appeal that imported furniture should not be classified as medical furniture. ${ }^{26}$ The importer claimed that the proper classification was medical furniture under tariff line 94/2. ${ }^{27}$ The Court of Cassation found that the goods were classifiable as "other furniture" under item $94 / 3$ of the tariff schedule and should not be admitted duty-free. It noted that the imported furniture was metal tables with wheels. The Court of Cassation further noted that imported furniture to be classified as medical furniture must be specially designed

\footnotetext{
${ }^{23}$ See Journal of Jordanian Bar Association, Decision No. 95/1554, page 1368, Issue No. 6 (1996).

${ }^{24} I d .1369$.

${ }^{25} I d .1370$.

${ }^{26}$ See Journal of Jordanian Bar Association, Decision No. 94/1543, page 3451, Issue No. 11 \& 12 (1995).

${ }^{27}$ The importer argued that the customs transaction indicated the value of each piece of the imported furniture at JD400, an amount that was high enough to prevent use of the imported furniture at homes. Moreover, the importer claimed that since tariff line 94/2 used general description "medical, surgical, dental or veterinary furniture" and the examples listed in the tariff line were not intended to be exhaustive, the imported furniture should have been classified under tariff line 94/2. Id. 3453.
} 
and intended for medical and surgical use. ${ }^{28}$ The Court found that the imported furniture was of broad nature and general use. ${ }^{29}$

An importer imported electrical machinery, including radio with sound recorder, from Japan. ${ }^{30}$ The Customs Department classified imported radio with sound recorder under item $85 / 15$ subject to $45 \%$ duty rate. ${ }^{31}$ The importer challenged the Customs Department's classification asserting that imported radio and sound recorder fell under item 85/15/a subject to $30 \%$ duty rate. The Customs Court of Appeal found that imported radio with sound recorder should have been classified under tariff item $85 / 15 /$ c subject to $30 \%$ tariff. $^{32}$ However, the Court of Cassation did not agree with reading of the Customs Court of Appeal and reversed its decision. First, it held that item 85/15 covered radio and television machinery. According to the rules of interpretation of the tariff schedule, radio and television machinery category included transmission apparatus incorporating sound recording apparatus subject to $45 \%$ tariff. $^{33}$

The Court of Cassation addressed the case of a product described by reference to a component material. ${ }^{34}$ In that case, the imported product was worked gold covered with zircon. In other words, the imported product consisted of two components: gold and zircon. The Court made the findings that gold predominated and gave the imported product its essential character. ${ }^{35}$ Accordingly, imported worked gold covered with gems

\footnotetext{
${ }^{28}$ Id. 3455.

${ }^{29}$ Id. 3456.

${ }^{30}$ See Journal of Jordanian Bar Association, Decision No. 91/662, page 870, Issue No. 4 \& 5 (1993).

${ }^{31}$ Id. 872.

${ }^{32}$ The Customs Court of Appeal decided that item 85/15/a included radio with gramophone and it did not explicitly cover sound recorder. Moreover, item 92/11 differentiated between gramophone and other sound recorders. Thus, item 85/15/a included only radio with gramophone and it did not include sound recorder. Id.

${ }^{33}$ Id. 873.

${ }^{34}$ See Journal of Jordanian Bar Association, Decision No. 90/644, page 2186, Issue No. 9, 10 \& 11 (1991).

35 Id. 2190.
} 
could be imported duty-free based on the decision of Council of Ministers which permitted importation of worked gold duty-free. ${ }^{36}$ Thus, the Court of Cassation may have used value and quantitative analysis in arriving at its conclusion. In other words, it may have determined that gold in terms of value and quantity exceeds other components such as zircon.

The Court of Cassation in another case quoted the rule of specificity in classifying imported tractor tracks. ${ }^{37}$ The imported tractor tracks were described in two provisions of the tariff schedule: tariff line $84 / 23$ dutiable at $1 \%$ and tariff line $87 / 6$ dutiable at $30 \% .{ }^{38}$ While the Court of Cassation found the imported tractor tracks classifiable under both tariff lines, it ruled that tariff line $84 / 23$ most specifically described tractor tracks.

The Court of Cassation ruled on a case that involved the classification of parts. ${ }^{39}$ In that case, imported products were electric motors of TV aerials or antenna. The importer argued that the imported products should have been classified under tariff line 85/a of the tariff schedule subject to $20 \%$ duty rate. However, the Court of Cassation noticed that TV aerials or antenna fell under tariff line 85/15/c/a. The Court of Cassation decided that as a general rule of the tariff schedule imported parts that are fit only for use in specific products are classifiable under the tariff provision of those products. ${ }^{40}$ As such, since electric motors are fit only for use in TV aerials, then electric motors were classifiable under heading 85/15/c/a and thus dutiable at $40 \%$ duty rate. As noticed, the Court of Cassation addressed the case of imported parts that are fit only for use in specific product.

\footnotetext{
36 The decision of Council of Ministers addressed importation of worked gold duty-free but did not address importation of worked gold covered with gems. Id.

${ }^{37}$ See Journal of Jordanian Bar Association, Decision No. 93/993, page 2181, Issue No. 9 \& 10 (1994).

${ }^{38}$ Id. 2183.

${ }^{39}$ See Journal of Jordanian Bar Association, Decision No. 93/1226, page 2205, Issue No. 9 \& 10 (1994).

${ }^{40}$ Id. 2208.
} 
Therefore, optional accessories or parts not fit only for use in specific products do not necessarily fall under the headings of these products.

In essence, customs classification of imported products is about choosing between two or more competing tariff lines. The Court of Cassation may consult rules of interpretation of the integrated tariff schedule of the Arab League, opinions of the Customs Cooperation Council, scientific authorities, testimony of witnesses, and other information to determine the meaning of a tariff provision. ${ }^{41}$ The Court of Cassation's reasoning in classification cases deserves some note. The Court of Cassation in some cases agreed with the lower court decisions while in other cases it overruled their decisions. In different set of cases, the Court of Cassation upheld and respected the decisions of the Customs Department which has the expertise in the field. In customs classification cases, the plaintiff had the burden of proving that Customs Department's classification is not right and that the claimed classification is correct. The Court of Cassation used, on a case-by-case basis, different means to classify imports due the wide variety of products.

Once an imported product is properly classified, customs value must be determined for the purpose of assessing the appropriate tariff. Customs standards in Jordan were streamlined in accordance with WTO rules. Among the more important changes was a standardized method for imposing duties. While in the past seemingly questionable methodologies were used in customs valuation now customs duties would become more

\footnotetext{
${ }^{41}$ See Journal of Jordanian Bar Association, Decision No. 89/669, page 1193, Issue No. 6, 7 \& 8 (1991). See Journal of Jordanian Bar Association, Decision No. 95/1067, page 162, 164, Issue No. 1, 2 \& 3 (1996). See also Journal of Jordanian Bar Association, Decision No. 90/1104, page 2332, Issue No. 12 (1991).
} 
predictable. Customs duties would be based on the WTO Customs Valuation Agreement. $^{42}$

Jordan shifted from the normal value scheme and database pricing to transaction value in computing tariffs. ${ }^{43}$ The normal value calculated tariffs based on the price goods would fetch in an open market between a buyer and a seller independent of each other. In database pricing, customs officials used prices stored and collected in databases to determine tariffs for imported products. Under the new customs valuation system, transaction value means that tariffs levied on imports shall be based on the invoice price as agreed by the importer and exporter. ${ }^{44}$

Transaction value is the primary basis for determining customs value. However, Customs Law of 1998 lays down rules and guidelines on how to determine customs value whenever customs officials have reasonable ground to doubt the authenticity of the declared import value. ${ }^{45}$ Customs officials could use the price of product when sold domestically in cases where transaction value cannot be determined or the computed value of the product. ${ }^{46}$

Customs valuation rules in Jordan mirror the language concerning customs valuation as set out in the WTO Customs Valuation Agreement. The new Jordanian valuation system has the advantage of stability and consistency in evaluating the value of imported

\footnotetext{
${ }^{42}$ Jordan confirmed that it would fully implement the WTO Customs Valuation Agreement from date of accession without recourse to any transitional period. See Working Party Report, supra note 223, at 94. According to article 20.1 of the WTO Customs Valuation Agreement, developing countries were given until Jan. 1, 2000 to implement its provisions. However, the Customs Valuation Agreement contains provisions for extending the deadlines.

${ }^{43}$ In mid-1996, a reference price database for valuation of products had been initiated, but this database no longer existed. See Working Party Report, at 90.

${ }^{44}$ Customs value could include the cost of loading, transport, and insurance as long as this is made on the basis of objective and quantifiable data. See Customs Law No. 20 of 1998, art. 28.

${ }^{45} I d$. art. 29.

${ }^{46}$ Id. 30.
} 
products and thus will encourage trade. It could help speed the movement of goods since it requires the Customs Department to release imported goods immediately. Under the old valuation system customs officials could have more discretion. Normal value and databases pricing could be fixed at levels higher than the actual price of imported products resulting in higher tariffs. The new valuation system would leave little room for the discretion of customs officials. Additionally, the new valuation system should contribute toward a more transparency.

Since Jordan did not have the advantage of additional time to set up the necessary infrastructure to ensure compliance, it could face technical, administrative, and financial problems in implementing and complying with the complicated WTO Agreement on Customs Valuation. ${ }^{47}$ The implementation of the WTO Customs Valuation Agreement could stretch the capabilities of the already understaffed Customs Department. The Customs Department has to retrain its personnel for the new valuation system. To meet concerns regarding fraud and undervaluation, Jordan could introduce post-entry audits so as to give customs officials the authority to audit accounts and commercial documents to detect the accuracy of customs declarations. Moreover, Jordan could exchange information with the exporting country on the value of export products.

\section{Rules of Origin}

Rules of origin determine where an imported product has been manufactured. This is important for different reasons. For example, rules of origin determine whether preferential tariff rates would apply to products of countries with which Jordan has free

\footnotetext{
${ }^{47}$ See Lael Brainard, Ready for Launch? The Prospects for Global Trade Negotiations, 19 BROOKINGS REV. 14, 16 (2001) (implementing trade agreements can be extremely costly for developing countries. Some estimate that a typical developing country must spend $\$ 150$ million to implement just three of the WTO's many agreements on intellectual property, customs valuation, and technical standards).
} 
trade agreements. Rules of origin also play an important role in administering trade remedy laws.

Jordan committed in its accession to the WTO that it would comply fully, as of date of accession, with the WTO Agreement on Rules of Origin. ${ }^{48}$ The WTO Agreement on Rules of Origin seeks to establish uniformity in the application of non-preferential rules of origin. ${ }^{49}$ Until the harmonization process is completed, WTO members apply their own rules of origin subject to certain general principles set out in article 2 of the WTO Agreement on Rules of Origin. Additionally, article IX of GATT 1994 sets forth rules for country of origin marking.

Generally, three tests are used to determine whether an imported product originates in a named country. These are substantial transformation, value added, and the hybrid approach. Under the substantial transformation test a product becomes the product of the most recent exporting country in which substantial transformation has occurred. A derivative rule of substantial transformation test, known as tariff shift method, is change in tariff classification. The second test is the value added test in which a product is considered to be of the last exporting country in which a specified percentage of value was added. The final alternative method is the hybrid test which combines substantial transformation and value added tests.

\footnotetext{
${ }^{48}$ See Working Party Report, at 100.

${ }^{49}$ The WTO Agreement on Rules of Origin established a three-year plan, undertook by the WTO Committee on Rules of Origin, leading toward global harmonization of non-preferential rules of origin for some 5000 product tariff lines. The harmonization process should have ended in 1998. However, this deadline was extended until the fourth WTO Ministerial Conference in Doha of 2001 or the end of 2001 at the latest as had been suggested by the Chairman of the Committee on Rules of Origin. See Committee on Rules of Origin, Nov. 29, 2000, WTO Doc. No. G/RO/M/33, at para 2.1. However, the 2001 deadline and several other deadlines were passed without achieving consensus over the harmonization work program. The newest deadline was fixed at the end of 2002. See Committee on Rules of Origin-Report by the Chairman of the Committee on Rules of Origin to the General Council, July 15, 2002, WTO Doc. No. $\mathrm{G} / \mathrm{RO} / 52$, at para 1.2.
} 
Articles 24-27 of Customs Law of 1998 provide the legal framework for the application of rules of origin. They spell out non-preferential rules of origin and leave for every free trade agreement its own rules of origin test. ${ }^{50}$ A product is considered to originate in a country if it is wholly grown, produced or manufactured in that country. ${ }^{51}$ The "products wholly obtained" rule is the easy rule of origin. It relates to products such as mineral products, some agriculture products, and sea products.

Due to the internationalization of manufacturing, a product could be produced in more than one country. In this case, the product is considered to originate from the country where it last underwent a substantial transformation by demonstrating tariff shift or minimum content. ${ }^{52}$ A product is considered to be substantially transformed if there has been a shift in tariff classification at the six-digit level under the tariff schedule of Jordan rather than the eight-digit level. A product is also considered to be substantially transformed by meeting a $40 \%$ minimum value added. However, there are several criteria that may make meeting the last substantial transformation test complicated. ${ }^{53}$

A certificate of origin must accompany an imported product. ${ }^{54}$ Transportation of imported products through the territory of a third country does not affect country of origin determination. For example, shipment of paper rolls of Portuguese origin through a German port for final destination in Jordan did not change the fact that the products were manufactured in Portugal. ${ }^{55}$ However, if imported products have been subject to further manufacturing operations when passing through the territory of a third country, then the

\footnotetext{
${ }^{50}$ See Customs Law No. 20 of 1998, art. 27.

${ }^{51} I d$. art. 24.a.

${ }^{52}$ Id. art. 24.c. The rule of substantial transformation in Customs Law of 1998 reflects the WTO rules of origin system which is based on the principle of substantial transformation.

${ }^{53}$ For example, Customs Law of 1998 lists specific manufacturing operations such as minor processes which are deemed insufficient to confer origin. $I d$. art. $24 . c \& \mathrm{~d}$.

${ }^{54} I d$. art. 26.

55 See Journal of Jordanian Bar Association, Decision No. 95/1241, page 194, Issue No. 1, 2 \& 3 (1996).
} 
imported products could be said to originate in the third country depending on the nature of the manufacturing operations.

Non-preferential rules of origin in Customs Law of 1998 seem to avoid the subjective nature of the last substantial transformation test by linking this transformation to a change in tariff heading or meeting the appropriate value-added content. Although the linkage may achieve predictability and transparency in theory, it may prove difficult in practice. Certificate of origin and other export documents may further create more paperwork. For example, certificate of origin could require listing specific product, specific exporter and specific importer. Certificate of origin could be valid for one transaction and for a limited duration. Moreover, due to the highly technical nature of rules of origin, customs officials would have to deal with complex cases on how imported products would qualify.

\section{Drawback}

Drawback is a refund or remission, in whole or part, under qualified circumstances of a customs duty, tax, or fee that is paid on imported materials upon subsequent exportation or used in the production of products that are then exported. Drawback is not tariff deferral or exemption rather it provides for reimbursement. The purpose of drawback is to compensate exporters for customs duty paid on inputs. Drawback also reduces costs for manufacturers thus enhancing competitiveness of domestic industries. Customs Law of 1998 provides several types of drawbacks. It allows drawback on specific grounds.

The first type of drawback is manufacturing drawback. Manufacturing drawback occurs when certain imported materials are used in products manufactured in Jordan and then exported. ${ }^{56}$ According to this type of drawback, there are three conditions that have to be met to qualify for a drawback. First, there must be importation of certain materials.

\footnotetext{
${ }^{56}$ See Customs Law No. 20 of 1998, art. 145.
} 
Second, imported materials must be used in manufacturing. Finally, the final product must be exported. Customs officials and courts would have to deal with issues such as defining manufacturing or imported materials for purpose of claiming drawback. ${ }^{57}$ Other types of drawback include same condition drawback. ${ }^{58}$ Claim for same condition drawback exists when an imported product is exported in the same condition as when it was imported. The crucial element for claiming this type of drawback is "same condition". Defining "same condition" may require engaging in analyzing when and what type of manufacturing operations could render same condition drawback inapplicable.

Customs Law of 1998 sets out other types of drawbacks. Drawback is allowed on imported products which are exported for not conforming to specifications. ${ }^{59}$ Further Customs regulations would have to detail eligibility requirements, procedures for drawback claim, types of duties subject to drawback, and drawback rates. Customs regulations would also have to list the type of products subject to drawback.

\section{Jordan's Harmonized Schedule}

Jordan uses the Convention on the Harmonized Commodity Description and Coding System as a basis for its national customs tariffs. ${ }^{60}$ The Harmonized System is an

\footnotetext{
${ }^{57}$ The Court of Cassation established a test for determining whether a product is manufactured. In holding that freezing of vegetables did not constitute manufacturing the Court of Cassation stated that manufacturing means change. There must be transformation into a new product in terms of its appearance, type or nature. See Journal of Jordanian Bar Association, Decision No. 99/3084, page 205, 209-210, Issue No. 1, $2 \& 3$ (2003). In another case, the Court of Cassation determined that if there was a registration of customs declaration with the Customs Department for imported product, then there was importation. See Journal of Jordanian Bar Association, Decision No. 93/1482, page 2184, Issue No. 9 \& 10 (1994) (it is settled in jurisprudence that imported products are defined as foreign products that have been shipped from abroad and entered the customs territory of Jordan accompanied with customs declaration registered with customs authorities as first step for clearance. Therefore, products are not considered imported unless customs declaration is registered regardless of date of arrival or date of unloading).

${ }^{58} I d$. art. 146.

${ }^{59} \mathrm{Id}$. art. 147.

${ }^{60}$ The Convention entered into force on January 1, 1988 with 36 contracting parties, including Jordan, ratified it. See Hironori Asakura, The Harmonized System and Rules of Origin, 27 J. World Trade 5, 8 (1993).
} 
international six-digit commodity classification developed under the auspices of the Customs Cooperation Council. ${ }^{61}$ Individual countries could extend it to 8 digits for export purposes and to ten digits for customs purposes. ${ }^{62}$

The Harmonized System is divided into 21 sections. Each of these sections groups together goods produced in the same sector of the economy. Each section comprises one or more chapters, with the entire nomenclature being composed of 97 chapters. Some chapters are reserved for future use. For example, section one (Chapters 1-5) covers live animals and products thereof, section two (Chapters 6-14) covers vegetable products, and section three (Chapter 15) covers animal and vegetable fats and oils.

In the Harmonized System goods are classified by what they are. The Harmonized System nomenclature is logically structured by economic activity or component material. For example, animals and animal products are found in one section and machinery and mechanical appliances, which are grouped by function, are found in another. Chapters of sections I to XV are grouped by biological structure or by the component material from which articles are made. For those chapters in which goods are grouped by raw material, a vertical structure is used in which articles are often classified according to their degree of processing: raw materials, semi-manufactured, and manufactured products. For example, Chapter 44 contains items such as rough wood, wood roughly squared and some wooden finished products such as wooden tableware. Articles may also be classified according to the use or function. The classification by function mainly occurs in section XII and sections XVI-XXI. For example, section XVII contains chapters 88 (aircraft) and 89 (ships).

\footnotetext{
${ }^{61}$ See The International Convention on the Harmonized Commodity Description and Coding System, June 14, 1983, 1035 U.N.T.S. 3.

${ }^{62} I d$. art. 3.3.
} 
Jordan Harmonized Tariff Schedule (“JHTS") is updated regularly extending over 9241 tariff lines. ${ }^{63}$ It is represented in a tabular format incorporating 4 columns, each with specific information. The first column is the H.S Code with 4 and/or 6 digits. In other words, this column is the Heading/Subheading column. Jordan as part of its HS system, in some cases, replaced the fifth and/or the sixth digit with "0" or " 00 " in accordance with article 4.3 of the Harmonized System Convention. The second column is the "article description" column which contains description of the product. The third column is "Collection Unit" which determines the unit of measure. The entire collection unit column in JHTS is based on value. The fourth column appears under the heading "Duty Rate" which contains the different tariff rates that apply to the product in question. ${ }^{64}$ JHTS does not contain a column marked "stat. Suffix" for collecting trade data.

Jordan Harmonized Tariff Schedule (2004)

\begin{tabular}{|l|l|l|l|}
\hline H.S. Code & Description & Collection Unit & Duty Rate \\
\hline
\end{tabular}

\footnotetext{
${ }^{63}$ The tariff schedule is accessible at the Customs Department website. See <http://www.customs.gov.jo/downloads.asp> (last visited March 31, 2018).

${ }^{64}$ The U.S. bases its rates of duty into three different tariff levels for all importable goods based on classifications of countries. Column 1 tariffs apply on the basis of MFN to all countries. Column 1 tariffs have been lowered over time through the GATT/WTO rounds of negotiations. Within column 1 there is a special rate of duty for imports from countries that the U.S. has a free trade agreement with such as Israel, Mexico, Canada, and Jordan or recipients of the Generalized System of Preferences, the Caribbean Basin Initiative, and the Andean Initiative. Column 2 tariffs, the highest level of tariffs, apply to countries denied MFN status such as non-market economies. Column 2 tariffs were enacted at the peak of the U.S. trade protectionist era in 1930s. They have not been lowered since their implementation. See Tariff Act of 1930, 497, 46 Stat. 590 (1930). The U.S. harmonized tariff schedule is prepared for publication by the Office of Tariff Affairs and Trade Agreements and published by the Office of Statistics of the ITC.
} 


\begin{tabular}{|c|c|c|c|}
\hline 8527.00000 & $\begin{array}{l}\text { Reception apparatus for radio-telephony, radio- } \\
\text { telegraphy or radio-broadcasting, whether or not } \\
\text { combined, in the same housing, with sound } \\
\text { recording or reproducing apparatus or a clock }\end{array}$ & & \\
\hline 8527.10000 & $\begin{array}{l}\text { Other radio-broadcast receivers, including } \\
\text { apparatus capable of receiving also radio- } \\
\text { telephony or radio-telegraphy }\end{array}$ & & \\
\hline 8527.12000 & Pocket-size radio cassette-players & Value & $30 \%$ \\
\hline 8527.13000 & $\begin{array}{l}\text { Other apparatus combined with sound recording } \\
\text { or reproducing apparatus }\end{array}$ & Value & $30 \%$ \\
\hline 8527.19000 & Other & Value & $30 \%$ \\
\hline 8527.20000 & $\begin{array}{l}\text { Radio-broadcast receivers not capable of } \\
\text { operating without an external source of power, } \\
\text { of a kind used in motor vehicles, including } \\
\text { apparatus capable of receiving also radio- } \\
\text { telephony or radio-telegraphy: }\end{array}$ & & \\
\hline
\end{tabular}

Almost 98 percent of JHTS is based on ad valorem tariff set as percentage of the value of the imported product. ${ }^{65}$ For example, if imported pocket-size radio cassette-players, tariff line 852712000 , valued JD100 were subject to 30 percent ad valorem tariff, then JD30 must be paid upon importation. In few cases, Jordan's HS has mixed or compound tariff that consists of ad valorem tariff and specific tariff, the latter being flat rate set per quantity or unit. For example, tariff line 010410000 of imported sheep is subject to 5

\footnotetext{
${ }^{65}$ Ad valorem tariff rate is assessed on the basis of CIF which includes the costs of imported products in the country of origin at the time of clearance plus any other costs incidental to delivery at the port of entry in Jordan such as insurance and freight.
} 
percent ad valorem tariff and JD2 per head. Therefore, one could say that ad valorem tariffs cover most tariff lines in Jordan.

The JHTS does not contain quotas, meaning that Jordan abolished quantitative import restrictions. It is a rationalized not a complex tariff schedule. ${ }^{66}$ Tariffs rates are in the following six bands: zero, $5,10,15,20$,and $30 \%$ with the exception of tobacco, manufactured tobacco substitutes and alcoholic beverages which are subject to prohibitive rates in the range of 50\%-180\%, and unwrought gold which is subject to $0.5 \%$. One can immediately notice that Jordan's tariffs are concentrated on few levels and not on a wide range of tariffs. There is no multiplicity of tariff rates that would involve many different types and levels of tariff. Thus, JHTS structure renders greater tariff uniformity.

In addition, imported products into Jordan are subject to general sales tax ("GST"). On the basis of national treatment principle, the same GST must be imposed on domestic products as well. However, if there is no local production of the imported product, then the general sales tax on imported products will be a tariff-equivalent rate. A special sales tax is imposed on certain imported products such as vehicles in addition to GST.

Perhaps, the only complex part of Jordan's tariff system is that concerned with imported vehicles. Currently, imported automobiles are taxed, excluding general and/or special sales taxes, at 10 percent to 30 percent duty rate depending on vehicle age or weight. ${ }^{67}$ For example, passenger cars less than five years old would be subject to 25 percent tariff rate. Trailers would be subject to 10 percent tariff rate. Buses and cars for

\footnotetext{
${ }^{66}$ For example, Jordan's tariff schedule does not have complex tariffs that would assess a tariff rate on the basis of a maximum or minimum rate or on the basis of a product's attributes.

${ }^{67}$ See How can You make a Self-Assessment of Duties and taxes Payable on your car? at <http://www.customs.gov.jo/viewins.asp?id=222\&title=Instructions> (last visited May 11, 2018).
} 
transport ten or more persons with diesel engine would be subject to 15 percent tariff rate.

The vehicle tariff system does not use for example a flat rate say of 10 percent on all vehicles. Moreover, it does not allow for a special tariff section for fuel economy or hybrid vehicles. ${ }^{68}$

Customs personnel would compute the value of imported vehicles as a function of basic requirements. For 2004 models, price lists represented by car agents in Jordan would be used. ${ }^{69}$ Prior to 2004 models pricing must cover depreciation of equipment using a depreciation schedule. For example, while for 2005 models there is no depreciation, for 2004 models an 85 percent depreciation rate applies.

Jordan's vehicle tariff system raises two interesting points. First, it presumes that the declared value of a car is dubious. In other words, it presumes the guilt of an importer for fraud. Second, it seems that the Customs Department uses price catalogues to determine the customs valuation of imported vehicles. This might result in arbitrary customs values. Moreover, it seems that such reference prices are contrary to the WTO Customs Valuation Agreement which requires the use of the imported goods' actual transaction value unless Jordan asked for WTO permission to continue applying reference price on imported vehicles. One may predict that Jordan uses price catalogues for imported vehicles as a result of consistent undervaluation by importers.

In approaching future rounds of trade negotiations, Jordan may want to argue in favor of mathematical formula (linear cuts) in which tariff rate applies across the board

\footnotetext{
${ }^{68}$ However, a note attached to the calculation method states that standard safety and environment equipments value is exempted from tariffs and general sales tax, provided it does not exceed 15 percent of the car value. $I d$.

69 To calculate duties/taxes payable on a car, the customs department states "you should know the value of your car, which may not necessarily be the value you declared or the car purchase price. It is in fact the price lists presented by car agents in Jordan for the brand new (2005) models". Id.
} 
with lower tariff cut per tariff line. The reason for this approach is the nature of Jordan's tariff schedule as currently stands. Close to 2131 tariff lines are above $20 \%$ tariff rate while about 7110 tariff lines are set below that percentage. Therefore, harmonization formula, which applies higher cuts on higher tariffs and lower cuts on lower tariffs, may not be desired.

There may be a need also to exempt certain imported inputs from tariffs and other domestic taxes. It would reduce production costs for domestic producers. In turn, this approach would help Jordan's manufacturing sector and give it a much needed competitiveness through cost savings.

\section{Free Economic Zones}

Jordan confirmed in its accession to the WTO that free zones or export processing zones would be fully subject to the coverage of the commitments taken in the protocol of accession. ${ }^{70}$ Free economic zone is a geographically defined, isolated, enclosed and policed area where certain types of economic activity take place without some of the government taxation and regulations that applies to the rest of the economy. ${ }^{71}$ In other words, it is considered to be outside the national customs territory for purposes of the tariff laws.

Most developing countries have begun to shift from import-substitution to exportlooking trade policies. One dimension of this has been the establishment of special economic zones for such economic activity as export promotion or industrial

\footnotetext{
${ }^{70}$ See Working Party Report, at 164.

${ }^{71}$ See Free Zones Corporation Law No. 32 of 1984, art.2, Official Gazette No. 3280 (Dec. 16, 1984), as amended by Provisional Law No. 41 of 2003, Official Gazette No. 4598 (May. 15, 2003).
} 
development. ${ }^{72}$ They are considered as one of the government's development tools to promote its exports. The purpose of these areas is to attract foreign capital, foreign technology, and managerial skills. ${ }^{73}$

In this context, free zones in Jordan are governed by the Free Zone Corporation that manages economic, trade, and industrial affairs in the zones. ${ }^{74}$ The law, moreover, rests the responsibility for the construction of buildings and the provision of infrastructure and services upon the Corporation. The Corporation may be burdened by such obligations. To establish a free zone the Corporation may declare any area as a free trade zone. ${ }^{75}$ Such an announcement shall specify scope of activities to be carried out in the zone concerned. ${ }^{76}$ Thus, the law allows for restrictions in terms of types of activities that can be carried out in the zone. In addition to storage and manufacture of goods, the law allows economic

\footnotetext{
${ }^{72}$ See John R. McIntyre, Rajneesh Narula \& Len J. Trevino, The Role of Export Processing Zones for the Host Countries and Multinationals: A Mutually Beneficial Relationship? X:4 THE INT'L TRADE J. 435, 440 (1996) (the first two zones established in developing countries were Mayaguez, Puerto Rico (1962) and Kandla, India (1965)).

${ }^{73}$ One of the main benefits of establishing free economic zones is the relocation of production from developed to developing countries with the hope of exploiting the low cost of labor. They also play an important part in the evolution of the new international division of labor. Another rationale for free zones is to generate foreign exchange needed for debt servicing. Another impact on domestic firms results from the close contact with foreign firms. This leads to intra-firm growth and domestic sub-contracting. However, the concept of special economic zones has been criticized on a number of grounds. The thrust of this criticism is that free economic zones have limited success in the development of developing countries economies. First, most zones employ mainly low skilled workers with lax labor codes and health and safety standards. One of their supposed advantages, the generation of employment through the attraction of foreign firms, has its limitations, in terms of the type of jobs generated and the long-term sustainability of these jobs. As far as zone-host economy backward linkages are concerned, there is normally very little technology transfer from free zones to the host country. The value of tax incentives granted to firms operating in free zones is also debatable. Therefore, the revenue forgone and social cost incurred in establishing free zones could be higher than actual benefits. Id. 441-452.

${ }^{74}$ The Free Zone Corporation Board is composed of the Minister of Finance as chairman, the director general of the Free Zone Corporation, and members from the MIT, Ministry of Finance/Customs Service, Ministry of Transportation, and the Central Bank. With regards to the governance of free zones there are three types: a free zone in which management of investment is vested into the Corporation, a free zone in which a private company is responsible for its administration subject to the Corporation's regulations, and a free zone in which it is run by private-public companies. $I d$. art.4, $2 \& 6$. It is noticeable the absence of private sector representatives from the composition of the Board. The Board is an organ of the government. As to free zone governance, it is questionable whether private operators have the necessary capital and expertise to run free zones.

${ }^{75} I d$. art. 4.a.

${ }^{76}$ Id. art. 4.f.
} 
operators in the zones to provide services as well. ${ }^{77}$ Special conditions in terms of impact on environment need to be attached to a licensed enterprise in a free zone. ${ }^{78}$ Other conditions include development, free zone-domestic market ties, and labor skills. ${ }^{79}$

The law offers enterprises lucrative packages consisting of an array of economic incentives. Enterprises are exempted from paying income tax on profits. ${ }^{80}$ They are permitted repatriation of investment or profits attributable to investments they make. Imports into a free zone are not to be subjected to tariffs and other types of taxes. ${ }^{81}$ The law is silent on the legal process for the settlement of disputes between a licensed enterprise and the Corporation or between two or more licensed enterprises within a free zone.

The free zones which have been established are divided into public and private free zones. There are 6 public free zones including Zarqa free zone established in 1983, Sahab free zone established in 1997, Queen Alia Airport free zone established in 1998, and AlKarak free zone established in 2001. In addition to these public free zones, there are 25 private free zones. For example, Jordan-Indo Chemicals Company, Hejazi \& Gousheh Company, Trans-Jordan Livestock Company, and the Private Free Zone at Jordanian airports.

Compliance with WTO commitments means economic incentives such as tax breaks given by Jordan through free zones, which are in fact investment and export promotion programs, are illegal (prohibited because export-contingent subsidies or actionable

\footnotetext{
${ }^{77} I d$. art. 2.

${ }^{78} I d$. art. 4.g. However, the language as written does not permit challenges by environmental groups regarding the potential impact of increased economic activity as a result of the establishment of a free zone. Absurdly, there is no specific provision on worker's rights of domestic staff.

${ }^{79} I d$. art. 13.b.

${ }^{80} I d$. art. 13.c.

${ }^{81} I d$.
} 
because they cause adverse effects). These programs have to be phased out under article 27.4 of the WTO SCM Agreement which mandates that developing countries, with the exception of sub-Saharan African countries, phase out export subsidies within eight years period in a progressive manner ending Jan.1, 2003. However, the SCM Agreement permits developing countries to seek an extension to deadline provided that requests are submitted at least a year before the expiration of the deadline. ${ }^{82}$ As such, Jordan may request a waiver for its export subsidies facilitated through free zones. ${ }^{83}$ Ultimately, Jordan has to phase put these programs.

In a bid to attract foreign companies, tax incentives such as preferential corporate income tax rate, reducing corporate taxes, long income tax holiday, deduct expenses approved for training and research, and valuable deductions for capital costs such as depreciation and inventory expenditures for companies operating in industrial parks and export processing zones would interfere with the neutrality of the tax system in Jordan. Moreover, these incentives mean less revenue for the government. Some would argue that in putting these incentives in place Jordan must be cautious not to fall in the trap where multinationals play Jordan against other countries due to the former's desperate

\footnotetext{
${ }^{82}$ Decisions regarding granting extensions are made by the Committee on Subsidies and Countervailing Measures with extension reviewed annually.

${ }^{83}$ In Nov. 2004, the Committee on Subsidies and Countervailing Measures took the action of extending export subsidies by developing countries, including Jordan, for an additional year until the end of 2005. See Transition Period Extended for Export Subsidies of Developing Countries, Nov. 4, 2004, WTO News. At the Doha Ministerial Conference of 2001, in response to demands from developing countries, members agreed to provide more flexible terms for requests of extension than those set in the SCM Agreement. Now, approved requests would be renewed on annual basis automatically until 2007on the condition that the country concerned does not modify its subsidy program in order to make it more favorable to domestic companies and transparency obligations are met in terms what type of measures a country wants to keep in place. Additionally, the export subsidy program must be in the form of full or partial exemptions from tariffs and internal taxes. It must be in existence before Sep. 1, 2001. Finally, the country in question must not have a share in world merchandise trade exports more than 0.10 percent or $\$ 20$ billion gross national income for 2000.
} 
drive for foreign investment. Others would argue that any lost revenue could be offset by any revenue generated through economic growth.

\section{References}

Asakura, Hironori. The Harmonized System and Rules of Origin, 27 J. World Trade 5 (1993).

Brainard, Lael. Ready for Launch? The Prospects for Global Trade Negotiations, 19 BROOKINGS REV. 14, 16 (2001).

Committee on Rules of Origin, Nov. 29, 2000, WTO Doc. No. G/RO/M/33.

Customs Law No. 20 of 1998, art. 65, Official Gazette No. 4305 (Oct. 1, 1998) as amended by Law No. 27 of 2000, Official Gazette No. 4443 (July 2, 2000).

Free Zones Corporation Law No. 32 of 1984, art.2, Official Gazette No. 3280 (Dec. 16, 1984), as amended by Provisional Law No. 41 of 2003, Official Gazette No. 4598 (May. 15, 2003).

Journal of Jordanian Bar Association, Decision No. 95/1554, page 1368, Issue No. 6 (1996).

Journal of Jordanian Bar Association, Decision No. 94/1543, page 3451, Issue No. 11 \& 12 (1995).

Journal of Jordanian Bar Association, Decision No. 91/662, page 870, Issue No. 4 \& 5 (1993).

Journal of Jordanian Bar Association, Decision No. 90/644, page 2186, Issue No. 9, 10 \& 11 (1991).

Journal of Jordanian Bar Association, Decision No. 93/993, page 2181, Issue No. 9 \& 10 (1994).

Journal of Jordanian Bar Association, Decision No. 93/1226, page 2205, Issue No. 9 \& 10 (1994).

Journal of Jordanian Bar Association, Decision No. 89/669, page 1193, Issue No. 6, 7 \& 8 (1991). See

Journal of Jordanian Bar Association, Decision No. 95/1067, page 162, 164, Issue No. 1, $2 \& 3$ (1996). 
Journal of Jordanian Bar Association, Decision No. 90/1104, page 2332, Issue No. 12 (1991).

Pruzin, Daniel. WTO Approves Accession of Jordan to Trade Body, 17 Int'l. Trade. Rep. 29 (BNA) (Jan. 6, 2000).

Moore, Pete W. Doing Business in the Middle East: Politics and Economic Crisis in Jordan and Kuwait (2004).

Staging Annex, Jordan Schedule of Market Access on Goods at <http://www.wto.org/english/thewto_e/countries_e/jordan_e.htm>.

The International Convention on the Harmonized Commodity Description and Coding System, June 14, 1983, 1035 U.N.T.S. 3.

McIntyre, John R., Rajneesh Narula, and Len J. Trevino. The Role of Export Processing Zones for the Host Countries and Multinationals: A Mutually Beneficial Relationship? X:4 THE INT'L TRADE J. 435 (1996) 